Acta Zoológica Mexicana (nueva serie), Volume 37, 1-13.

Original paper

\title{
Social correlates of variation in urinary oxytocin concentrations of mantled howler monkeys Alouatta palliata (Gray, 1849) (Primates: Atelidae): A preliminary assessment
}

\author{
Correlatos sociales de la variación en las \\ concentraciones de oxitocina urinaria de \\ monos aulladores de manto Alouatta palliata \\ (Gray, 1849) (Primates: Atelidae): Una \\ evaluación preliminar
}

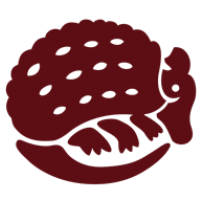

OPEN ACCESS

*Corresponding author:

iD Pedro Américo D. Dias paddias@hotmail.com

Cite:

Moreno-Espinoza, D., Dias, P. A. D.

Coyohua-Fuentes, A., Canales-

Espinosa, D., Rangel-Negrín, A. (2021) Social correlates of variation in urinary oxytocin concentrations of mantled howler monkeys Alouatta palliata (Gray, 1849) (Primates: Atelidae): A preliminary assessment. Acta Zoológica Mexicana (nueva serie), 37, 1-13. 10.21829/azm.2021.3712319 elocation-id: e3712319

Received: 24 August 2020

Accepted: 22 June 2021

Published: 15 July 2021
DiANA MORENO-ESPINOZA, (D) *PEDRO AMÉRICO D. DIAS, ALEJANDRO COYOHUA-FUENTES, DOMINGO CANALES-ESPINOSA, ARIADNA RANGEL-NEGRÍN

Primate Behavioral Ecology Lab, Instituto de Neuroetología, Universidad Veracruzana, Av. Dr. Luis Castelazo Ayala S/N Colonia Industrial Animas, Xalapa, Veracruz, 91190, México.

Responsible editor: Juan Carlos Serio-Silva

ABSTRACT. There is growing evidence that non-human primate sociality is linked to proximate neuroendocrine mechanisms. Arginine vasopressin, endorphins, and oxytocin may be involved in such mechanisms. Here, we perform a preliminary analysis of the social correlates of variation in urinary oxytocin concentrations in mantled howler monkeys (Alouatta palliata). From January to December 2017, we studied 13 adult mantled howler monkeys belonging to two groups. We recorded the occurrence of social interactions (547.5 observation hours); assessed proximity among group members $(2,194$ instantaneous recordings); and collected 172 urine samples. Urine samples were assayed (ELISA) for oxytocin concentrations, which were corrected for specific gravity, resulting in 54 analyzed samples. Hormone concentrations increased by approximately $62 \%$ when individuals were involved in affiliative interactions. With respect to when no affiliative interactions occurred, urinary oxytocin concentrations were higher when 
Moreno-Espinoza et al.: Social correlates of oxytocin variation in Alouatta palliata

dyads with a low-quality social relationship affiliated. These results agree with previous contentions that this hormone is linked to participation in affiliative interactions. Convergence between these and results from other taxa supports the hypothesis that the biological mechanisms that allow for primate sociality are shared among species.

Key words: affiliation; Alouatta; neuroendocrine mechanisms; platyrrhines; sociality

RESUMEN. Existe una creciente evidencia de que la sociabilidad en primates no humanos está relacionada con mecanismos neuroendocrinos. La arginina vasopresina, las endorfinas y la oxitocina pueden estar involucradas en tales mecanismos. Aquí, realizamos un análisis preliminar de los correlatos sociales de la variación en las concentraciones de oxitocina urinaria en monos aulladores de manto (Alouatta palliata). De enero a diciembre de 2017, estudiamos 13 monos aulladores de manto adultos pertenecientes a dos grupos. Registramos la ocurrencia de interacciones sociales (547.5 horas de observación); evaluamos la proximidad entre los miembros del grupo (2.194 registros instantáneos); y recolectamos 172 muestras de orina. Analizamos las muestras de orina (ELISA) para determinar las concentraciones de oxitocina, las cuales corregimos por la gravedad específica, lo que resultó en 54 muestras analizadas. Con respecto a cuando no ocurrieron interacciones afiliativas, las concentraciones de oxitocina aumentaron aproximadamente un $62 \%$ cuando los individuos participaron en interacciones afiliativas, y las concentraciones de oxitocina fueron mayores cuando díadas con una relación social de baja calidad se afiliaron. Estos resultados convergen con propuestas previas de que la oxitocina está vinculada a la participación en interacciones afiliativas. La convergencia entre estos resultados y los reportados para otros taxa apoya la hipótesis de que los mecanismos biológicos que permiten la sociabilidad de los primates se comparten entre las especies.

Palabras clave: afiliación; Alouatta; mecanismos neuroendocrinos; platirrinos; sociabilidad

\section{INTRODUCTION}

Most diurnal primates live in permanent social groups, where individuals enjoy benefits but also face costs (Alberts, 2018). Given that competition is a pervasive consequence of group living and that it may negatively affect survival and reproduction (e.g., Altmann \& Alberts, 2003; Packer et al., 1995), mechanisms that favor the maintenance of sociality despite competition should be under strong selective pressure (Aureli et al., 2012). The proximate neuroendocrine mechanisms underlying sociality in non-human primates have been explored (Massen et al., 2010), and there is indirect evidence that arginine vasopressin, endorphins, and oxytocin may be involved in such mechanisms (Insel, 2010).

In mammals, oxytocin is linked to female reproductive physiology, particularly in the peripartum period: it is responsible for uterine contractions during labor; it stimulates milk ejection; and it is involved in mother-offspring bonding and maternal behavior (Anestis, 2010). However, oxytocin also plays an important role in the formation of social bonds and social preferences, social recognition, and trust (Beery \& Zucker, 2010; Meyer-Lindenberg et al., 2011; Anacker \& Beery, 2013; Benarroch, 2013; Crockford et al., 2013). This hormone may favor sociality through its 
influence on the brain reward system: oxytocin release results in increased dopamine concentrations, which are involved in reward and pleasure processes (Love, 2014). These processes in turn affect social bonds with conspecifics because dopamine influences the assignment of motivational value or relevance (Liu \& Wang, 2003; Love, 2014). Thus, oxytocin may be part of a positive feedback mechanism underlying socialization. This mechanism is both associated with positive interactions with peers (i.e., affiliation) and agonistic behavior (De Dreu, 2012; Anacker \& Beery, 2013; Fujii et al., 2016; Samuni et al., 2016; Benítez et al., 2018; Cavanaugh et al., 2018; Rincon et al., 2020). In the latter, oxytocin facilitates the categorization of individuals as belonging to the same or another group, promoting cooperation and trust toward ingroup peers, but fear and distrust towards outgroup individuals (De Dreu, 2012; Fujii et al., 2016).

Here, we perform a preliminary analysis of the social correlates of variation in urinary oxytocin concentrations in mantled howler monkeys (Alouatta palliata). Howler monkeys live in groups with relatively stable composition and high spatial cohesion (Crockett \& Eisenberg, 1987), despite having a low rate of social interactions (Wang \& Milton, 2003; Bezanson et al., 2008). Given that the relationship between oxytocin and social behavior has been typically assessed in primate species with comparatively higher rates of social interactions (e.g., cotton-top tamarins, Saguinus oedipus: Snowdon et al., 2010; Pan troglodytes: Crockford et al., 2013; Witting et al., 2014; capuchin monkeys, Sapajus apella: Benítez et al., 2018; Barbary macaques, Macaca sylvanus: Rincon et al., 2020), howler monkeys are an interesting model for examining convergence and divergence in the proximate mechanisms underlying primate sociality (Anacker \& Beery, 2013). We hypothesized that variation in urinary oxytocin concentrations of mantled howler monkeys should be linked to social factors. We tested two predictions of this hypothesis. First, as oxytocin is linked to social affiliation and contact, we predicted higher concentrations when individuals exchanged affiliative interactions with peers than when they did not. Second, because oxytocin associates with the expression of social preferences, we predicted higher concentrations following affiliation between peers with a high-quality than between those with a low-quality social relationship.

\section{MATERIALS AND METHODS}

Study site and subjects. From January to December 2017, we studied mantled howler monkeys at La Flor de Catemaco, Veracruz, México ( $18^{\circ} 26^{\prime} 39^{\prime \prime} \mathrm{N}, 9^{\circ} 02^{\prime} 57^{\prime \prime} \mathrm{W}$ ). The study site is a 250-ha ranch that includes approximately 100 ha of mainly tall evergreen tropical forest. The climate is warm and humid with mean annual temperature of $25^{\circ} \mathrm{C}$ and rainfall of $2,600 \mathrm{~mm}$. We studied 13 adult mantled howler monkeys belonging to two groups (group $1=$ three adult males and three adult females, one juvenile, and one infant; group $2=$ three adult males and four adult females, two juveniles, and one infant). Studies at this site began in 2004 and since 2012 groups are sampled on a weekly basis. Subjects are fully habituated to the presence of researchers (i.e., they pay no attention to us, and our presence does not interfere with their behavior) and are easily recognized through anatomical and physiognomic characteristics.

Behavioral sampling. Behavioral sampling was conducted by a single observer with support from two to three field assistants. We recorded all-occurrences (Altmann, 1974) of affiliative (i.e., friendly and peaceful interactions exchanged between individuals with the function of developing, 
maintaining, or strengthening social bonds: Jasson del Toro \& Nekaris, 2019) and agonistic (i.e., social interactions that involve threatening, aggression, fighting, or submission: Young, 2019) social interactions as described in the ethogram of Dias \& Rangel-Negrín (2015; Table 1). We noted the type of interaction that was exchanged, the identities of the subjects that were involved, and each subject's role as either actor or receptor. We used scan sampling with instantaneous recording (Altmann, 1974) repeated at $15 \mathrm{~min}$ intervals to study proximity among all adult group members according to the following categories: contact; <1 m; 1-5 m; > $5 \mathrm{~m}$ (Van Belle et al., 2008; Wang \& Milton, 2003). We completed a total of 547.5 focal observation hours (group $1=288.5 \mathrm{~h}$; group $2=259 \mathrm{~h}$ ) and of 2,194 instantaneous recordings (group $1=1,174$; group $2=1,020$ ) .

Table 1. Social interactions recorded in this study.

\begin{tabular}{llll}
\hline $\begin{array}{c}\text { Type of } \\
\text { interaction }\end{array}$ & Behavior & \multicolumn{1}{c}{ Description } & $\begin{array}{c}\text { Rate } \\
\text { (int./h) }\end{array}$ \\
\hline Affiliative & Contact & $\begin{array}{l}\text { Actor places some part of its body in contact with the } \\
\text { receptor's body }\end{array}$ & 0.117 \\
\cline { 2 - 4 } & Grooming & $\begin{array}{l}\text { Actor touches some part of the receptor's body with its } \\
\text { fingers and gently manipulates its hair }\end{array}$ & 0.005 \\
\cline { 2 - 4 } & Hugging & Actor places its arms around the receptor's body & 0.005 \\
\cline { 2 - 4 } & Playing & $\begin{array}{l}\text { Individuals interact with rapid movements and physical } \\
\text { contact, including touching, biting, and chasing } \\
\text { without harming each other }\end{array}$ & 0.152 \\
\cline { 2 - 4 } & $\begin{array}{l}\text { Playing } \\
\text { invitation }\end{array}$ & $\begin{array}{l}\text { Actor approaches the receptor, reaching for him with } \\
\text { its hands and/or feet or with other quick movements }\end{array}$ & 0.002 \\
\cline { 2 - 4 } & Scratching & $\begin{array}{l}\text { Actor repeatedly moves its hand in some part of the } \\
\text { receptor's body }\end{array}$ & 0.002 \\
\cline { 2 - 4 } & Touching & $\begin{array}{l}\text { Transient contact (<5 s) between some part of the } \\
\text { actor and the receptor's body }\end{array}$ & 0.007 \\
\hline Ahasing & Actor moves toward a fleeing receptor & 0.018 \\
\cline { 2 - 4 } & Slapping & Actor hits the receptor with an open hand & 0.004 \\
\cline { 2 - 5 } & Supplanting & $\begin{array}{l}\text { Actor approaches the receptor and occupies its } \\
\text { position after the latter leaves }\end{array}$ & 0.022 \\
\cline { 2 - 4 } & Threatening & $\begin{array}{l}\text { Actor shakes and/or breaks branches looking toward } \\
\text { the receptor. May include vocalizations (roaring and } \\
\text { barking) and charges }\end{array}$ & 0.031 \\
\hline
\end{tabular}

Urine collection and analysis. We determined oxytocin concentrations in urine samples. We collected 172 samples immediately after deposition that were matched with individuals and were uncontaminated by soil or feces as well as by urine from other individuals. We collected urine with insulin syringes from a plastic sheet positioned underneath subjects during urination or directly from vegetation to $1.5 \mathrm{ml}$ Eppendorf microcentrifuge tubes. We labeled each tube with subject identity, date, and hour of collection and placed tubes in a cooler with gel ice packs while in the 
field. We stored samples in a freezer at $-20^{\circ} \mathrm{C}$ at the field station (Catemaco, Veracruz) and shipped them in dry ice at the end of fieldwork to the Primate Behavioral Ecology Lab at the Instituto de Neuroetología (Xalapa, Veracruz), where they were stored again at $-40^{\circ} \mathrm{C}$. Time of collection (linear mixed model of hour of collection on oxytocin concentrations per sample with subject identity as a random factor: $\chi^{2}=0.13, P=0.723$ ) and storage duration (linear mixed model of days to assay on oxytocin concentrations per sample with subject identity as a random factor: $\chi^{2}=0.01, P=$ 0.961) did not affect oxytocin concentrations.

We determined oxytocin concentrations in unextracted urine samples with an enzymelinked immunosorbent assay (ELISA) at the Instituto de Investigaciones Cerebrales (Universidad Veracruzana). We used a commercial kit (Oxytocin ELISA Kit (ab133050), Abcam PLC, UK; sensitivity $=15 \mathrm{pg} / \mathrm{ml}$, calibration range $=15.6-1,000 \mathrm{pg} / \mathrm{ml}$ ) in an IMARK microplate reader (Bio-Rad Laboratories, Inc., CA, USA) following the manufacturer's instructions. The antibody in this kit is highly specific for oxytocin, showing low cross-reactivity with [Arg8]-vasotocin (7.5\%) and mesotocin (7\%). Although this assay has not been tested before in howler monkeys, it has been validated in various primate species, including humans, tamarin monkeys, and chimpanzees (Bick \& Dozier, 2010; Snowdon et al., 2010; Witting et al., 2014). We ran all samples in duplicate. Serial dilutions of five samples yielded results that ran parallel to the kit's standards $\left(R^{2}=0.8, F=1.4, P\right.$ $=0.265)$. Mean recovery of oxytocin was $89.7 \%(N=6)$. Mean coefficient of variation for intraassay replicates was $7.1 \%(N=6)$ and $7.5 \%$ for inter-assay replicates $(N=3)$.

We conducted a biological validation of collection, preservation, and assay methods by comparing oxytocin concentrations between females in the peripartum period and cycling females. Specifically, we predicted that peripartum females should have higher oxytocin concentrations than cycling females due to the involvement of oxytocin in labor and lactation (Kumaresan et al., 1979; Spinolo et al., 1992; Neuman, 2003). We classified females in peripartum from one week before to one week after parturition. For this validation, we used samples that were not associated with participation in social interactions and that were not used in further analysis $(N$ cycling $=11, N$ peripartum $=9)$. Females in the peripartum period had urinary oxytocin concentrations that were on average $25 \%$ higher than those of cycling females (linear mixed model with female identity as a random factor: $\chi^{2}=2.13, P=0.041,95 \%$ C.I. $=0.01-1.01$; Fig. 1 ). Thus, our procedures allow assessing variation in urinary oxytocin of mantled howler monkeys associated with the biological functions of this hormone.

We corrected oxytocin concentrations by specific gravity to account for variation among samples in urine volume and concentration (Miller et al., 2004). Each sample's specific gravity was divided by mean specific gravity across all samples (1.02) and this value was multiplied by oxytocin concentration. We determined specific gravity with a pocket refractometer (PAL-10S, Atago, U.S.A., Inc., WA, USA). One hundred and eighteen samples did not have enough volume to be analyzed for both oxytocin and specific gravity, so we report results for 54 samples (mean \pm SD $=4.2 \pm 1.9$ samples per subject). 


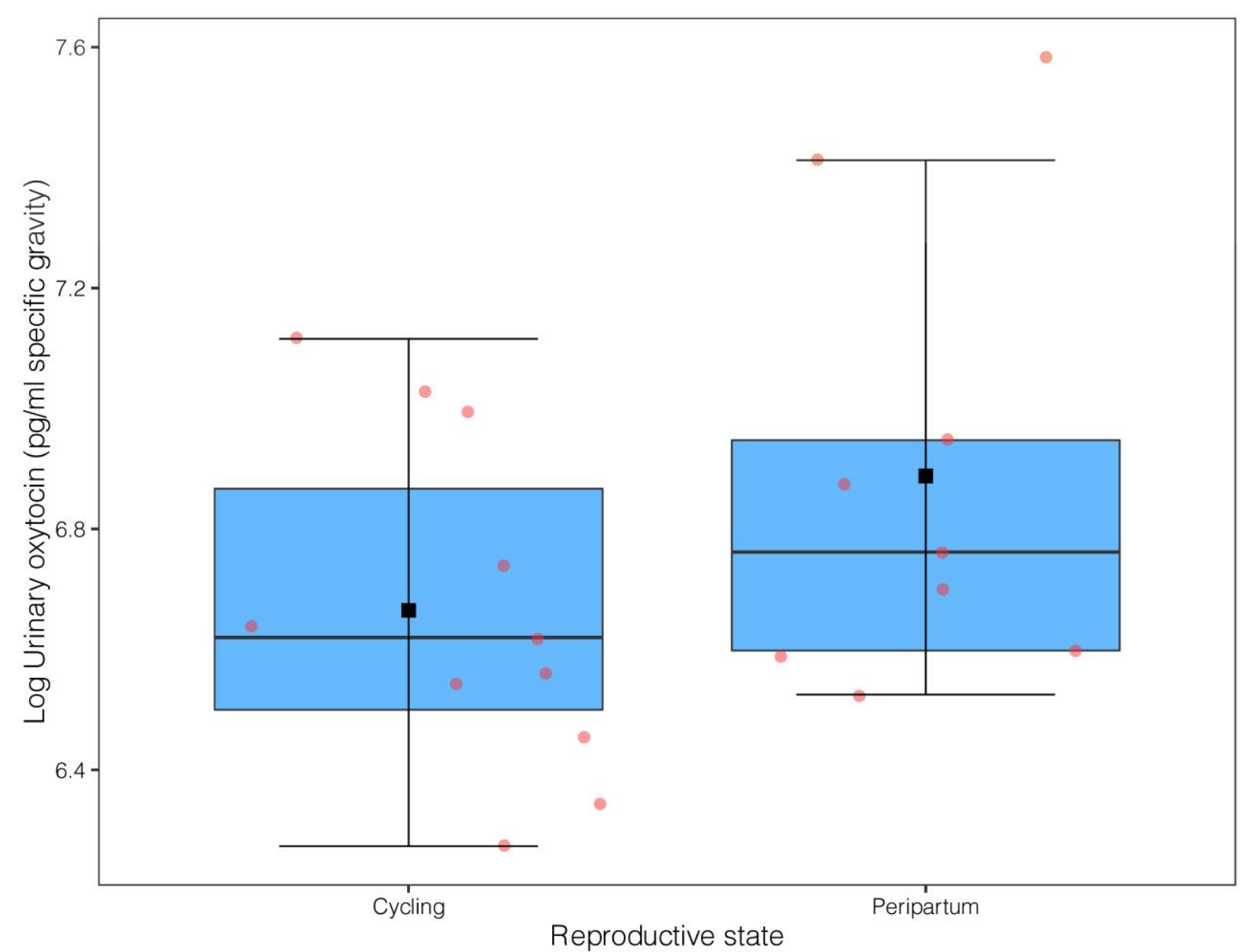

Figure 1. Variation in urinary oxytocin concentrations (corrected for specific gravity) between cycling and peripartum mantled howler monkey females (Alouatta palliata). Thick lines inside the boxes are the medians; black squares are the means; box limits are the 25 th and $75^{\text {th }}$ percentiles; whiskers indicate $1.5^{\star}$ interquartile ranges; data points are red circles.

Data organization. Following previous studies that have demonstrated a 15-60 min latency from the exogenous administration of oxytocin to an elevation in urinary levels of this hormone (humans: Amico et al., 1987; marmosets: Seltzer \& Ziegler, 2007; capuchin monkeys: Benítez et al., 2018), we classified each sample as associated ( $15<$ collection $<60 \mathrm{~min}$ from an interaction) or not associated (15>collection $>60 \mathrm{~min}$ from an interaction) with the occurrence of affiliative interactions.

We defined a composite index of social relationship quality for each dyad with the following measures: 1) rate of affiliative interactions, calculated as the frequency of affiliation divided by the observation time for each dyad;2) rate of agonistic interactions, calculated as the frequency of agonism divided by the observation time for each dyad; 3) reciprocity in the exchanging of affiliative interactions as: 


$$
\text { Reciprocity }=\frac{\text { Affiliation A-Affiliation B }}{\text { Affiliation A+Affiliation B }}
$$

Where Affiliation $A$ is the number of times individual $A$ directed affiliative interactions at $B$, and Affiliation $B$ is the number of times individual $B$ directed affiliative interactions at $A$. This index ranges between 1 ( $A$ was always the actor) and -1 ( $B$ was always the actor), with zero indicating absolute reciprocation (Ryu et al., 2014); 4) proximity as:

$$
\text { Dyadic proximity index }=\frac{\sum_{1}^{n}\left(\text { contact }^{\star} 1\right)+(<1 \mathrm{~m} * 0.67)+\left(1-5 \mathrm{~m}^{\star} 0.33\right)+\left(>5 \mathrm{~m}^{\star} 0\right)}{\text { Total number of instantaneous recordings for the dyad }}
$$

In this index, we summed the frequency of recordings in which the dyad was observed in each proximity category after multiplying frequencies by a decreasing weighing factor, such that a dyad always observed in contact would have an index of 1 whereas one that was always $>5 \mathrm{~m}$ would have an index of 0 (González-Hernández et al., 2014). We then divided this sum by the total number of instantaneous recordings for the dyad. These four measures proxy three components of social relationship quality: value (affiliation), compatibility (agonism and proximity), and security (reciprocity; Cords \& Aureli, 2000). We determined the quartiles of the four measures and assigned a value of 1 to each of the following quartiles: 1) third quartile of affiliation rate; 2 ) third quartile of proximity index; 3) first quartile of agonism rate; 4) first quartile of reciprocity index. Other quartiles were assigned a value of 0 . Our composite measure of social relationship quality was the sum of quartile values, and we considered that dyads with a quartile sum $>2$ had a high-quality social relationship.

Data organization and analysis. We used a linear mixed model to assess variation in logtransformed urinary oxytocin concentrations as a function of the participation in affiliative interactions (categorical predictor with two levels: yes, no) and social relationship quality of dyads that participated in affiliative interactions (categorical predictor with three levels: high-quality, lowquality, sample not associated with affiliative interaction). In this model, as well in the biological validation and temporal variation in hormone concentrations mentioned above: 1) we added identity as a random factor to account for repeated sampling of subjects; 2) assessed model fit visually via Q-Q plots and Shapiro-Wilks tests of model residuals, which indicated residual normality in all cases; 3 ) and to determine whether the fixed factors explained more variation in hormone concentrations than the random factors alone, we compared the complete models (i.e., with fixed and random factors) with a null model including only the response and the random variable with a likelihood ratio test (Pinheiro \& Bates, 2000). These tests were significant in all cases $(P<0.001)$, indicating a limited influence of the random factors on model results. Given the small number of samples that were analyzed, we diagnosed model stability via DFBETAS which indicated that model results were not affected by influential cases. We ran post-hoc Tukey pairwise comparisons to assess the significant influence of social relationship quality on urinary oxytocin concentrations. All analyses were performed with R 4.0.0. (R Core Team, 2020). 


\section{RESULTS}

Urinary oxytocin concentrations varied between 530.2 and 2,765.2 pg/ml with a mean of 1,192.4 $\pm 567.4 \mathrm{pg} / \mathrm{ml}$. The mixed model explained $50 \%\left(R^{2}=0.50\right)$ of the deviance in urinary oxytocin concentrations. Variation in urinary oxytocin concentrations was significantly related to the exchanging of affiliative interactions $\left(\chi^{2}{ }_{1}=33.0, P<0.001,95 \% \mathrm{Cl}=0.54-1.16\right.$; Fig. $\left.2 \mathrm{~A}\right)$ and the quality of the social relationship of dyads $\left(\chi_{2}^{2}=13.1, P=0.001,95 \% \mathrm{Cl}=0.29-1.09\right.$; Fig. $\left.2 \mathrm{~B}\right)$. Specifically, urinary oxytocin concentrations increased by approximately $62 \%$ when individuals were involved in affiliative interactions and, with respect to when no affiliative interactions occurred, urinary oxytocin concentrations were higher when dyads that had a low-quality relationship affiliated.
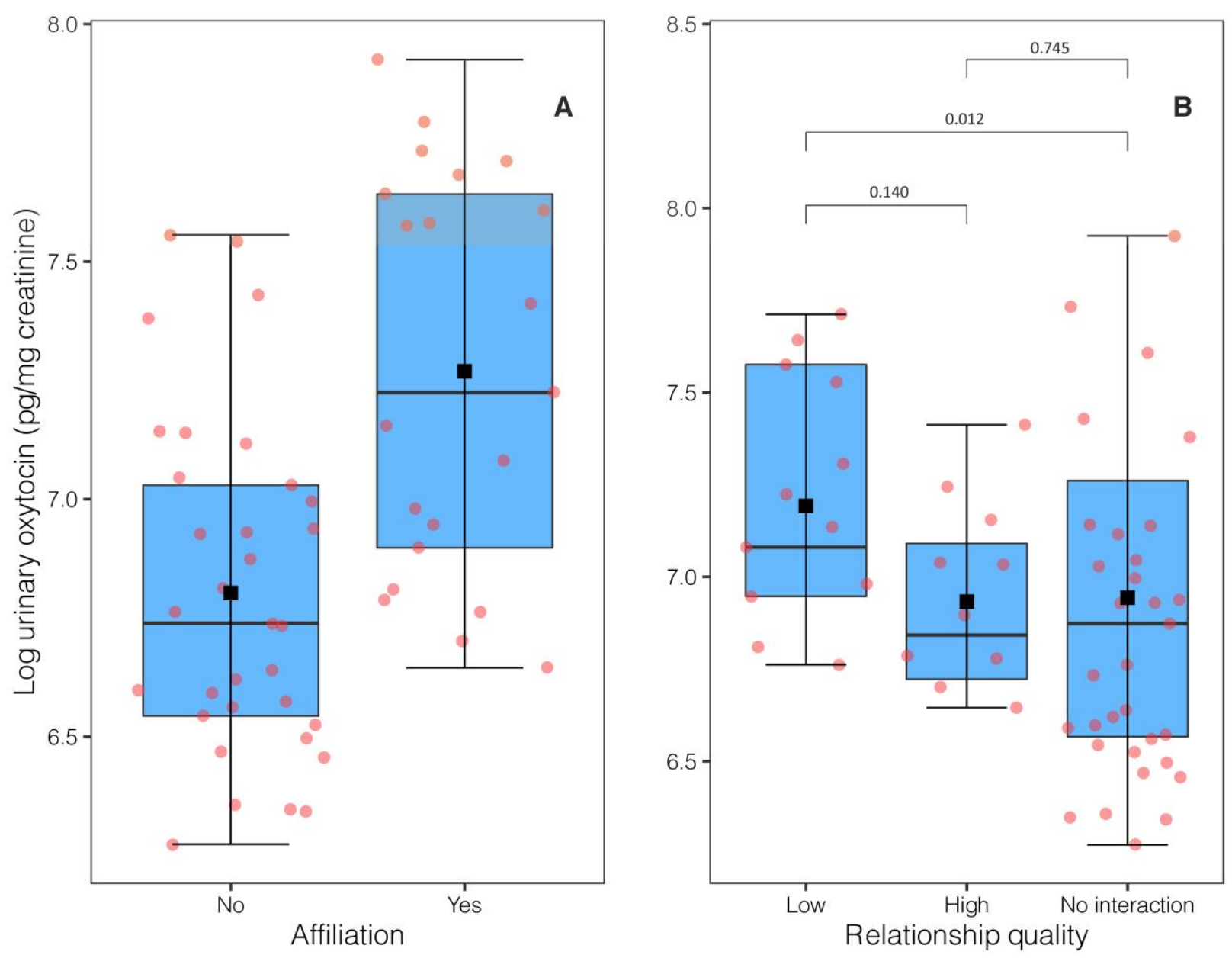

Figure 2. The influence of participation in affiliative interactions $(A)$ and dyadic social relationship quality (B) on urinary oxytocin concentrations (corrected for specific gravity, SP) in mantled howler monkeys (Alouatta palliata). Thick lines inside the boxes are the medians; black squares are the means; box limits are the 25 th and $75^{\text {th }}$ percentiles; whiskers indicate $1.5^{*}$ interquartile ranges; data points are red circles. In B, post-hoc pairwise comparisons were performed with Tukey contrasts. 


\section{DISCUSSION}

This is the first study to assess the relationship between social factors and oxytocin concentrations in howler monkeys. We found that hormone concentrations were higher when individuals affiliated than when no affiliation occurred and among dyads with low-quality social relationships that exchanged affiliation than when no affiliation occurred. Given the limited set of urine samples that could be assayed, these results provide preliminary evidence of the involvement of oxytocin in the regulation of the social behavior of mantled howler monkeys.

Urinary oxytocin concentrations of mantled howler monkeys were higher when individuals participated in affiliative interactions, a pattern also observed in capuchin monkeys, chimpanzees, common marmosets, Barbary macaques, and humans (Seltzer \& Ziegler, 2007; Morhenn et al., 2008; Witting et al., 2014; Benítez et al., 2018; Rincon et al., 2020). However, whereas the relationship between oxytocin concentrations following affiliation and the quality of social relationships is positive in chimpanzees (Crockford et al., 2013), it was negative in mantled howler monkeys. It must be noted, however, that howler monkeys affiliate at low rates compared to other primates and, contrary to chimpanzees, rarely groom (Di Fiore \& Campbell, 2007). Furthermore, most samples analyzed here that were associated with low-quality social relationships corresponded to affiliative interactions between males. In several howler monkey species, female dyads and female-male dyads have the strongest social bonds, whereas male-male interactions are infrequent and mostly agonistic (Di Fiore \& Campbell, 2007). It is thus possible that oxytocin is an influential mechanism in sociality among male howler monkeys. In this context, increased oxytocin concentrations may facilitate social interactions between males via anxiolytic effects, as proposed for Barbary macaques (Rincon et al., 2020). Given the small number of samples that were assayed here, examination of this possibility remains for future research.

Measurement of peripheral oxytocin in urine samples of non-human primates commonly involves a purification step (e.g., Benítez et al., 2018; Crockford et al., 2016). Extraction of urine samples reduces interference from other compounds, usually resulting in lower oxytocin concentrations in extracted than in unextracted samples (Ziegler, 2018). We did not purify urine of mantled howler monkeys, so our results pertain to oxytocin concentrations in unextracted samples. Thus, it must be determined if the association between oxytocin concentrations and social behavior reported here is also found when assaying extracted urine samples. Nonetheless, (i) significant oxytocin response in the 15-60 min period following affiliation that converges with studies based on extracted and unextracted urine samples (e.g., Boose et al., 2018; Crockford et al., 2013), (ii) positive results for the biological validation, (iii) positive results for analytical validations, and (iv) the specificity of the antibody that we used, seem to support the reliability of our methods.

\section{CONCLUSIONS}

We provide preliminary evidence that variation in urinary oxytocin concentrations of mantled howler monkeys is associated with social factors. Specifically, oxytocin increases after the participation of individuals in affiliative interactions and is linked to the quality of social relationships between individuals that affiliate. Similarity between these and results from other 
taxa support the hypothesis that the biological mechanisms underlying primate sociality are shared among species.

ACKNowledgments. We thank P. Cruz Miros and several volunteers and students for their invaluable help during fieldwork. La Flor de Catemaco granted permission to work at this site, and Ing. J. L. Ponce Puente facilitated our work in a variety of ways. We thank G. Coria for allowing us to carry out the hormonal analyzes in his laboratory, and to M. Barradas Moctezuma for her support and guidance during lab work. F. Aureli, J. C. Serio-Silva (Associate Editor), Z. Hirano, O. Chaves, and an anonymous reviewer provided valuable comments that helped to improve this study. A. Rangel-Negrín and P.A.D. Dias thank Mariana and Fernando for constant support and inspiration to study primate behavior. D. Moreno Espinoza thanks Ozzy, Judith, and Efrén for their constant support and motivation during this study. Our study was noninvasive and adhered to the "Guidelines for the treatment of animals in behavioral research and teaching" (Guidelines for the use of Animals, 2018). Research protocols were approved by the Secretaría de Medio Ambiente y Recursos Naturales (permits SGPA/DGVS/10637/11 and SGPA/DGVS/04999/14) and complied to the legal requirements of Mexican law (NOM-059-SEMARNAT-2010). The study was supported by Universidad Veracruzana (Dirección General del Área Biológico-Agropecuaria, Instituto de Neuroetología, and Posgrado en Neuroetología) and Consejo Nacional de Ciencia y Tecnología (beca maestría 611074; proyecto ciencia básica 254217). A. Rangel-Negrín and P. A. D. Dias were supported by grants from the Universidad Veracruzana (DGDAIE-CA-UV-25, Programa HAPI, Posgrado en Neuroetología) while preparing this manuscript.

\section{LITERATURE CITED}

Alberts, S. (2018) Social influences on survival and reproduction: Insights from a long-term study of wild baboons. Journal of Animal Ecology, 88, 47-66.

https://doi.org/10.1111/1365-2656.12887

Altmann, J. (1974) Observational study of behavior: Sampling methods. Behaviour, 49, 227-267. https://doi.org/10.1163/156853974X00534

Altmann, J., Alberts, S. C. (2003) Intraspecific variability in fertility and offspring survival in a nonhuman primate: Behavioral control of ecological and social sources. Pp. 140-169. In: K. W. B. Wachter, R. A. Bulatao (Eds.). Offspring: Human fertility behavior in biodemographic perspective. National Academies Press, Washington, DC.

Amico, J. A., Ulbrecht, J. S., Robinson, A. G. (1987) Clearance studies of oxytocin in humans using radioimmunoassay measurements of the hormone in plasma and urine. Journal of Clinical Endocrinology and Metabolism, 64, 340-345. https://doi.org/10.1210/jcem-64-2-340

Anacker, A. M., Beery, A. K. (2013) Life in groups: the roles of oxytocin in mammalian sociality. Frontiers in Behavioral Neuroscience, 7, 1-10.

https://doi.org/10.3389/fnbeh.2013.00185

Anestis, S. F. (2010) Hormones and social behavior in primates. Evolutionary Anthropology, 19, 6678.

https://doi.org/10.1002/evan.20253 
Aureli, F., Fraser, O. N., Schaffner, C. M., Schino, G. (2012) The regulation of social relationships. Pp. 531-551. In: J. C. Mitani, J. Call, P. M. Kappeler, R. A. Palombit, J. B. Silk (Eds.). The evolution of primate societies. Chicago University Press, Chicago.

Beery, A. K., Zucker, I. (2010) Oxytocin and same-sex social behavior in female meadow voles. Neuroscience, 169, 665-673.

https://doi.org/10.1016/j.neuroscience.2010.05.023

Benarroch, E. (2013) Oxytocin and vasopressin. Social neuropeptides with complex neuromodulatory functions. American Academy of Neurology, 80, 1521-1528. https://doi.org/10.1212/WNL.0b013e31828cfb15

Benítez, M. E., Sosnowski, M. J., Tomeo, O. B., Brosnan, S. F. (2018) Urinary oxytocin in capuchin monkeys: Validation and the influence of social behavior. American Journal of Primatology, 88, 1-11. https://doi.org/10.1002/ajp.22877

Bezanson, M., Garber, P. A., Murphy, J. T., Premo, L. S. (2008) Patterns of subgrouping and spatial affiliation in a community of mantled howling monkeys (Alouatta palliata). American Journal of Primatology, 70, 282-293. https://doi.org/10.1002/ajp.20486

Bick, J., Dozier, M. (2010) Mothers' concentrations of oxytocin following close, physical interactions with biological and nonbiological children. Developmental Psychobiology, 52, 100-107. https://doi.org/10.1002/dev.20411

Boose, K., White, F., Brand, C., Meinelt, A., Snodgradd, J. (2018) Infant handling in bonobos (Pan paniscus): Exploring functional hypotheses and the relationship to oxytocin. Physiology \& Behavior, 193, 154-166. https://doi.org/10.1016/j.physbeh.2018.04.012

Cavanaugh, J., Mustoe, A., French, J. A. (2018) Oxytocin regulates reunion affiliation with a pair mate following social separation in marmosets. American Journal of Primatology, 88, 1-9. https://doi.org/10.1002/ajp.22750

Crockett, C. M., Eisenberg, J. F. (1987) Howlers: Variations in group size and demography. Pp. 54-68. In: B. B. Smuts, D. L. Cheney, R. M. Seyfarth, R. W. Wrangham, T. T. Struhsaker (Eds.). Primate societies. University of Chicago Press, Chicago.

Crockford, C., Wittig, R., Langergraber, K., Ziegler, T., Zuberbühler, K., Deschner, T. (2013) Urinary oxytocin and social bonding in related and unrelated wild chimpanzees. Proceedings of The Royal Society, 280, e20122765. https://doi.org/10.1098/rspb.2012.2765

De Dreu, C. (2012) Oxytocin modulates cooperation within and competition between groups: An integrative review and research agenda. Hormones and Behavior, 61, 419-428. https://doi.org/10.1016/j.yhbeh.2011.12.009

Di Fiore, A., Campbell, C. J. (2007) The atelines: Variation in ecology, behavior, and social organization. Pp. 155-185. In: C. J. Campbell, A. Fuentes, K. C. MacKinnon, M. Panger, S. K. Bearder (Eds.). Primates in perspective. Oxford University Press, Oxford, NY.

Dias, P. A. D., Rangel-Negrín, A. (2015) An ethogram for the social behavior of adult Alouatta palliata mexicana and A. pigra. Laboratorio de Ecología del Comportamiento de Primates, Instituto de Neuroetología, Universidad Veracruzana, Xalapa, Veracruz, Mexico. 
https://doi.org/10.13140/RG.2.1.1043.7840

Fujii, T., Schug, J., Nishina, K., Takahashi, T., Okada, H., Takagishi, H. (2016) Relationship between salivary oxytocin levels and generosity in preschoolers. Scientific Reports, 6, 1-7. https://doi.org/10.1038/srep38662

González-Hernández, M., Rangel-Negrín, A., Schoof, V., Chapman, C., Canales-Espinoza, D., Dias, P. A. D. (2014) Transmission patterns of pinworms in two sympatric congeneric primate species. International Journal of Primatology, 35, 445-462.

https://doi.org/10.1007/s10764-014-9751-y

Insel, T. R. (2010) The challenge of translation in social neuroscience: A review of oxytocin, vasopressin, and affiliative behavior. Neuron, 65, 768-779.

https://doi.org/10.1016/j.neuron.2010.03.005

Jasso del Toro, C., Kekaris, K. A-I. (2019) Affiliative behaviors. Encyclopedia of animal cognition and behavior. Springer, New York.

https://doi.org/10.1007/978-3-319-47829-6_1040-1

Kumaresan, P., Subramanian, M., Anandarangam, P. B., Kumaresan, M. (1979) Radioimmunoassay of plasma and pituitary oxytocin in pregnant rats during various stages of pregnancy and parturition. Journal of Endocrinological Investigation, 2, 65-70. https://doi.org/10.1007/bf03349277

Liu, Y., Wang, Z. X. (2003) Nucleus accumbens oxytocin and dopamine interact to regulate pair bond formation in female prairie voles. Neuroscience, 121, 537-544. https://doi.org/10.1016/S0306-4522(03)00555-4

Love, T. M. (2014) Oxytocin, motivation and the role of dopamine. Pharmacology, Biochemistry and Behavior, 119, 49-60.

https://doi.org/10.1016/j.pbb.2013.06.011

Massen, J., de Voss, H., Sterck, E. (2010) Close social associations in animals and humans: functions and mechanisms of friendship. Behaviour, 147, 1379-1412. https://doi.org/10.1163/000579510X528224

Meyer-Lindenberg, A., Domes, G., Kirsch, P., Heinrichs, M. (2011) Oxytocin and vasopressin in the human brain: social neuropeptides. Nature Reviews Neuroscience, 12, 524-538. https://doi.org/10.1038/nrn3044

Miller, R., Brindle, E., Holman, D. J., Shofer, J., Klein, N. A., Soules, M. R., O'Connor, K. A. (2004) Comparison of specific gravity and creatinine for normalizing urinary reproductive hormone concentrations. Clinical Chemistry, 50, 924-932.

https://doi.org/10.1373/clinchem.2004.032292

Morhenn, V. B., Park, J. W., Piper, E., Zak, P. J. (2008) Monetary sacrifice among strangers is mediated by endogenous oxytocin release after physical contact. Evolution and Human Behavior, 29, 375-383.

https://doi.org/10.1016/j.evolhumbehav.2008.04.004

Neumann, I. D. (2003) Brain mechanisms underlying emotional alterations in the peripartum period in rats. Depression and Anxiety, 17, 111-121.

https://doi.org/10.1002/da.10070

Packer, C., Collins, D. A., Sindimwo, A., Goodall, J. (1995) Reproductive constraints on aggressive competition in female baboons. Nature, 373, 60-63.

https://doi.org/10.1038 / 373060a0 
Pinheiro, J., Bates, D. (2000) Mixed-effects models in S and S-plus. Springer, New York, NY, 528 pp.

R Core Team (2020) R: A language and environment for statistical computing. R Foundation for Statistical Computing, Vienna, Austria.

Rincon, A. V., Deschner, T., Schülke, O., Ostner, J. (2020) Oxytocin increases after affiliative interactions in male Barbary macaques. Hormones and Behavior, 119, 104661. https://doi.org/10.1016/j.yhbeh.2019.104661

Ryu, H., Hill, D. A., Furuichi, T. (2014) Prolonged maximal sexual swelling in wild bonobos facilitates affiliative interactions between females. Behaviour, 152, 285-311. https://doi.org/10.1163/1568539X-00003212

Samuni, L., Preis, A., Mundry, R., Deschner, T., Crockford, C., Wittig, R. M. (2016) Oxytocin reactivity during intergroup conflict in wild chimpanzees. Proceedings of the National Academy of Sciences, 14, 268-273. https://doi.org/10.1073/pnas.1616812114

Seltzer, L. J., Ziegler, T. E. (2007) Non-invasive measurement of small peptides in the common marmoset (Callithrix jacchus): A radiolabeled clearance study and endogenous excretion under varying social conditions. Hormones and Behavior, 51, 436-442. https://doi.org/10.1016/j.yhbeh.2006.12.012

Snowdon, C., Pieper, B., Boe, C., Cronin, K., Kurian, A., Ziegler, T. (2010) Variation in oxytocin is related to variation in affiliative behavior in monogamous, pairbonded tamarins. Hormones and Behavior, 58, 614-618. https://doi.org/10.1016/j.yhbeh.2010.06.014

Spinolo, L. H., Raghow, R., Crowley, W. R. (1992). Oxytocin messenger RNA levels in hypothalamic, paraventricular, and supraoptic nuclei during pregnancy and lactation in rats. Annals of the New York Academy of Sciences, 652, 425-428. https://doi.org/10.1111/j.1749-6632.1992.tb34373.x

Van Belle, S., Estrada, A., Strier, K. B. (2008). Social relationships among male Alouatta pigra. International Journal of Primatology, 29, 1481-1498. https://doi.org/10.1007/s10764-008-9309-y

Young, C. (2019) Agonistic behavior. Encyclopedia of animal cognition and behavior. Springer, New York. https://doi.org/10.1007/978-3-319-47829-6_320-1

Wang, E., Milton, K. (2003) Intragroup social relationships of male Alouatta palliata on Barro Colorado Island, Republic of Panama. International Journal of Primatology, 24, 1227-1243. https://doi.org/10.1023/B:IJOP.0000005989.29238.ce

Witting, R., Crockford, C., Deschner, T., Langergraber, K., Ziegler, T., Zuberbühler, K. (2014) Food sharing is linked to urinary oxytocin levels and bonding. Proceedings of the Royal Society, 281, e20133096.

https://doi.org/10.1098/rspb.2013.3096 